\title{
PENERAPAN METODE WEBQUAL 4.0 UNTUK PENGUKURAN KUALITAS WEBSITE BPRS AL SALAAM AMAL SALMAN
}

\author{
Puri Prasastiwi $^{1^{*}}$,Adiat Pariddudin ${ }^{2}$ \\ ${ }^{1}$ Sistem Informasi \\ STIKOM Binaniaga Bogor. \\ Email: puriprasastiwi@gmail.com \\ Email: adiat@stikombinaniaga.ac.id
}

\begin{abstract}
The BPRS Al-Salaam Amal Salman website (Al-Salaam Amal Salman Islamic Development Bank) is a website in the form of various BPRS information. The information submitted must be in accordance with the wishes of the community. The measurement of the quality of information on the BPRS Al-Salaam Amal Salman website aims to measure the quality of information held. By using the webqual method, which is to find out the value of the variables from the dimensions of the BPRS Al-Salaam Amal Salman website. The value obtained from each dimension is the usability value of 126 and entered into the accepted category, the value of the information dimension (information quality) obtained is 123 into the accepted category, the obtaining interaction quality value is 117 in. into the accepted category, and the overall value dimension of the overall quality (overall impression) is 123 into the accepted category. The usability dimension contributes a value of 0.317 with a low level of relationship, the dimension of information quality (information quality) contributes a value of 0.460 with a moderate level of relationship, and the dimension of interaction quality contributes a value of 0.561 with a moderate relationship.
\end{abstract}

Keywords: webqual, website, dimensions, variables.

\begin{abstract}
ABSTRAK
Website BPRS Al-Salaam Amal Salman (Bank Pembangunan Rakyat Syariah Al-Salaam Amal Salman) merupakan website berupa berbagai informasi BPRS. Informasi yang disampaikan harus sesuai dengan keinginan masyarakat. Pengukuran kualitas informasi pada website BPRS Al-Salaam Amal Salman bertujuan untuk mengukur kualitas informasi yang dimiliki. Dengan menggunakan metode webqual yaitu untuk mengetahui nilai variabel dari dimensi-dimensi terhadap website BPRS Al-Salaam Amal Salman. Nilai yang didapatkan dari setiap dimensi adalah nilai dimensi penggunaan (usability) memperoleh nilai 126 dan masuk ke dalam kategori diterima, nilai dimensi informasi (information quality) memperoleh adalah 123 masuk ke dalam kategori diterima, nilai dimensi interaksi (interaction quality) memperoleh adalah 117 masuk ke dalam kategori diterima, dan nilai dimensi keseluruhan kualitas website (overall impression) memperoleh adalah 123 masuk ke dalam kategori diterima. Dimensi penggunaan (usability) memberikan kontribusi nilai sebesar 0,317 dengan tingkat hubungan rendah, dimensi kualitas informasi (information quality) memberikan kontribusi nilai sebesar 0,460 dengan tingkat hubungan sedang, dan dimensi kualitas interaksi (interaction quality) memberikan kontribusi nilai sebesar 0,561 dengan tingkat hubungan sedang.
\end{abstract}

Kata Kunci: webqual, website, dimensi, variable 


\section{PENDAHULUAN}

Perkembangan teknologi saat ini sangat maju dengan pesat. Banyak perusahaan dengan berbagai bidang seperti pendidikan, kesehatan (rumah sakit), keuangan (perbankan) menggunakan teknologi yang sangat bermanfaat bagi pengguna maupun perusahaan tersebut. Dalam hal ini, teknologi sangat diperlukan guna mempermudah dalam mencari informasi, bertukar informasi dan menambah ilmu pengetahuan. Website merupakan penyajian informasi yang mudah disediakan oleh perusahaan, yang saat ini juga merupakan media yang paling banyak diakses oleh masyarakat. Penelitian ini dilakukan untuk mengukur kualitas website BPRS Al Salaam Amal Salman. BPRS Al Salaam Amal Salman (Bank Pembangunan Rakyat Syariah Al Salaam Amal Salman) merupakan perusahaan yang bergerak di bidang jasa keuangan atau perbankan yang melayani konsumen atau calon nasabah yang ingin mengajukan pembiayaan motor syariah. Untuk meningkatkan kualitas layanan kepada nasabah, BPRS Al Salaam Amal Salman perlu adanya pengukuran kualitas website.

Dalam pengukuran website BPRS Al Salaam Amal Salman, digunakan metode webqual 4.0. Webqual merupakan metode pengukuran kualitas website berdasarkan persepsi pengguna akhir (masyarakat). Berdasarkan pemodelan website quality (webqual), terdapat tiga dimensi kualitas website yang selanjutnya akan dipakai sebagai variabel bebas. Tiga dimensi kualitas website, yaitu kualitas penggunaan (usability), kualitas informasi (informaton quality), dan kualitas interaksi (interaction quality). Sedangkan variabel terikat adalah keseluruhan kualitas website (overall impression).

\section{METODE}

\section{Webqual}

Webqual adalah "a an webqual for assessing the usability, information, and service interaction quality of Internet web-sites, particularly those offering e-commerce facilities” (www.webqual.co.uk).

Webqual adalah sebuah alat untuk menilai kegunaan, kualitas informasi dan kualitas interaksi pelayanan dari halaman web pada internet, khususnya yang menggunakan fasilitas e-commerce.

\section{Uji validitas}

Validitas atau ketepatan yang menunjukkan sejauh mana suatu alat ukur mampu mengukur apa yang ingin diukur.

Untuk mengetahui pertanyaan atau pernyataan mana yang valid dan mana yang tidak valid, dengan mengkonsultasikan data tersebut dengan tingkat signifikan rtabel $=0,300$ apabila alat ukur tersebut berada $<0,300$ (tidak valid). Pengujian statistik mengacu pada kriteria:

rhitung < rtabel maka tidak valid

rhitung > rtabel maka valid

dengan rtabel $(\alpha ; n-2) n=$ jumlah sampel

Rumus korelasi product moment:

$$
r=\frac{n \cdot\left(\sum X Y\right)-\left(\sum X\right)\left(\sum Y\right)}{\sqrt{\left(n \cdot \sum X^{2}-\left(\sum X\right)^{2}\right) \cdot\left(n \cdot \sum Y^{2}-\left(\sum Y\right)^{2}\right)}}
$$


dimana :

n: jumlah responden

x: skor variabel (jawaban responden)

y: skor total dari variabel untuk responden ke-n

Uji reliabilitas

Uji keandalan dilakukan terhadap pertanyaan-pertanyaan atau pernyataan-pernyataan yang sudah valid.

Dikatakan reliabel jika nilai Cronbach's Alpha lebih besar dari nilai kritis. Nilai koefisien reliabilitas yang ditetapkan adalah antara 0,6 dan 0,7 (Sugiyono, 2003:124) yaitu :

Jika nilai koefisien reliabilitas (alpha) > 0,6 maka reliable

Jika nilai koefisien reliabilitas (alpha) $<0,6$ maka tidak reliable

Rumus Alpha Cronbach sebagai berikut :

Menentukan nilai varian setiap butir pertanyaan

$$
S_{i}=\frac{\sum X_{i}^{2}-\frac{\left(\sum X_{i}\right)^{2}}{N}}{N}
$$

Menentukan nilai varian total

$$
S_{t}=\frac{\sum X_{t}^{2}-\frac{\left(\sum X_{t}\right)^{2}}{N}}{N}
$$

Menentukan reliabilitas instrument

$$
r_{11}=\left(\frac{k}{(k-1)}\right)\left(1-\frac{\sum \sigma_{t}^{2}}{\sigma_{t}^{2}}\right)
$$

$\mathrm{N}=$ Jumlah sampel

$\mathrm{Xi}=$ Jawaban responden untuk setiap butir pertanyaan

$\sum \mathrm{x}=$ Total jawaban responden untuk setiap butir pertanyaan

$$
\sigma_{\mathrm{t}}^{2}=\text { Varian total }
$$

$\sum \sigma_{\mathrm{t}}^{2}=$ Jumlah varian butir

$\mathrm{k}=$ Jumlah butir pertanyaan

r11 = Koefisien reliabilitas instrument 
Perhitungan nilai setiap dimensi

Teknik perhitungan nilai setiap dimensi digunakan untuk mengetahui nilai dari setiap dimensi yang ada pada metode webqual 4.0. Metode yang digunakan adalah metode mean (rata-rata). Mean (nilai rata-rata) dengan rumus:

$\bar{x}=\frac{\sum X_{i}}{n}$

$\mathrm{x}=$ mean (rata-rata)

$\sum \mathrm{xi}=$ jumlah tiap data

$\mathrm{n}=$ jumlah data

Analisis regresi linear

sederhana Analisis regresi linear sederhana digunakan hanya untuk satu variabel bebas (independent) (X1, X2,...Xn) dengan satu variabel tak bebas (dependent) (Y). Langkah analisis regresi dan prosedur pengujiannya yaitu:

Nilai korelasi r Di dalam Walpole (1995), analisis korelasi adalah metode statistic yang digunakan untuk mengukur besarnya hubungan linier antara dua variabel atau lebih.

$$
r=\frac{n \cdot\left(\sum X Y\right)-\left(\sum X\right)\left(\sum Y\right)}{\sqrt{\left(n \cdot \sum X^{2}-\left(\sum X\right)^{2}\right) \cdot\left(n \cdot \sum Y^{2}-\left(\sum Y\right)^{2}\right)}}
$$

Uji t

Uji t digunakan untuk menguji pengaruh variabel independen secara parsial terhadap variabel dependen.

Kaidah pengujian:

Jika, -ttabel $<=$ thitung $<=$ tabel, maka Ho diterima

Jika, thitung > tabel, maka Ho ditolak

Menghitung thitung dan ttabel

Menghitung nilai thitung

$t=\frac{r \sqrt{n-2}}{\sqrt{1-r^{2}}}$

Menghitung nilai ttabel

Nilai tabel dapat dicari dengan menggunakan tabel t-Student. Bila pengujian dua sisi, maka nilai $\alpha$ dibagi 2 .

ttabel $=\mathrm{t}(\alpha / 2)(\mathrm{n}-2)$ 
Adapun menurut Sugiyono (2008:231) untuk menginterpretasikan hasil penelitian korelasi yang terdapat pada table 1 .

Tabel 1. Tabel interpretasi hasil korelasi

\begin{tabular}{|c|c|}
\hline Koefisien Korelasi & Tingkat Hubungan \\
\hline $0.00-0,199$ & Sangat rendah \\
\hline $0,20-0,399$ & Rendah. \\
\hline $0,40-0,599$ & Sedang \\
\hline $0,60-0,799$ & Kuat \\
\hline $0,80-1,000$ & Sangat kuat \\
\hline
\end{tabular}

\section{HASIL DAN PEMBAHASAN}

\section{Hasil}

Nilai dimensi penggunaan (usability) yang diperoleh adalah 126 masuk ke dalam kategori diterima, nilai dimensi informasi (information quality) yang diperoleh adalah 123 masuk ke dalam kategori diterima, nilai dimensi interaksi (interaction quality) yang diperoleh adalah 117 masuk ke dalam kategori diterima, dan nilai dimensi keseluruhan kualitas website (overall impression) yang diperoleh adalah 123 masuk ke dalam kategori diterima.

Dimensi penggunaan (usability) memberikan kontribusi nilai sebesar 0,317 dengan tingkat hubungan rendah, dimensi kualitas informasi (information quality) memberikan kontribusi nilai sebesar 0,460 dengan tingkat hubungan sedang, dan dimensi kualitas interaksi (interaction quality) memberikan kontribusi nilai sebesar 0,561 dengan tingkat hubungan sedang.

\section{Pembahasan}

Dimensi penggunaan (usability)

Tabel 2. Perhitungan nilai dimensi penggunaan (usability)

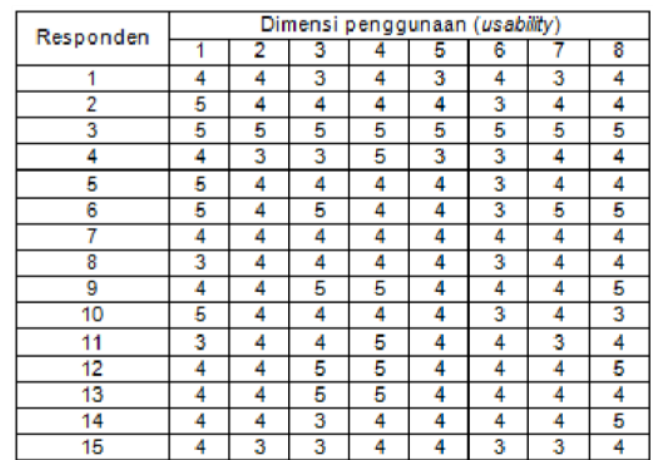




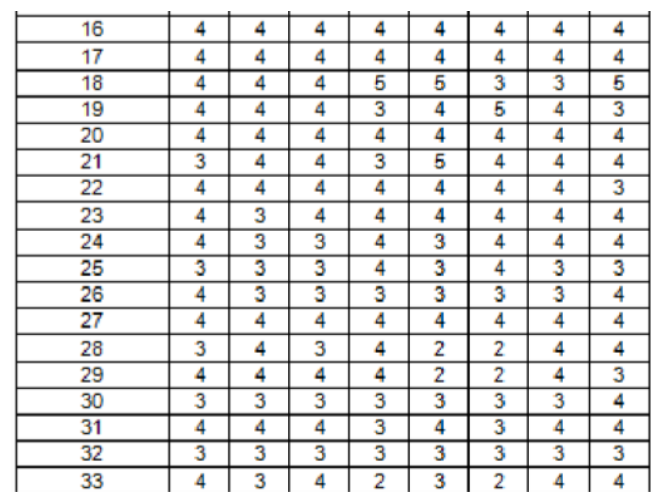

Tabel 3. Jumlah responden pada dimensi penggunaan (usability)

\begin{tabular}{|c|c|c|c|c|c|c|c|c|}
\hline \multirow{2}{*}{ Nilai } & \multicolumn{7}{|c|}{ Dimensi penggunaan (usability) } \\
\cline { 2 - 10 } & 1 & 2 & 3 & 4 & 5 & 6 & 7 & 8 \\
\hline 1 & 0 & 0 & 0 & 0 & 0 & 0 & 0 & 0 \\
\hline 2 & 0 & 0 & 0 & 1 & 2 & 3 & 0 & 0 \\
\hline 3 & 7 & 9 & 10 & 6 & 8 & 12 & 8 & 6 \\
\hline 4 & 21 & 23 & 18 & 19 & 20 & 16 & 23 & 21 \\
\hline 5 & 5 & 1 & 5 & 7 & 3 & 2 & 2 & 6 \\
\hline
\end{tabular}

Nilai dari variabel-variabel dan total nilai dimensi penggunaan (usability) terdapat pada table 4 .

Tabel 4. Total nilai dimensi penggunaan (usability).

\begin{tabular}{|c|c|c|c|c|c|c|c|c|}
\hline \multirow{2}{*}{ Nilai } & \multicolumn{7}{|c|}{ Dimensi penggunaan (usabiily) } \\
\cline { 2 - 10 } & 1 & 2 & 3 & 4 & 5 & 6 & 7 & 8 \\
\hline 1 & 0 & 0 & 0 & 0 & 0 & 0 & 0 & 0 \\
\hline 2 & 0 & 0 & 0 & 2 & 4 & 6 & 0 & 0 \\
\hline 3 & 21 & 27 & 30 & 18 & 24 & 36 & 24 & 18 \\
\hline 4 & 84 & 92 & 72 & 76 & 80 & 64 & 92 & 84 \\
\hline 5 & 25 & 5 & 25 & 35 & 15 & 10 & 10 & 30 \\
\hline Total & 130 & 124 & 127 & 131 & 123 & 116 & 126 & 132 \\
\hline
\end{tabular}

Skala kuesionernya dari 1 sampai dengan 5 yaitu :

Nilai 1 untuk sangat tidak setuju dikonversi menjadi sangat tidak diterima.

Nilai 2 untuk tidak setuju dikonversi menjadi tidak diterima.

Nilai 3 untuk netral dikonversi menjadi cukup diterima.

Nilai 4 untuk setuju dikonversi menjadi diterima.

Nilai 5 untuk sangat setuju dikonversi menjadi sangat diterima.

Mencari interval $=\frac{\text { nilai tertinggi }- \text { nilai terendah }}{\text { banyaknya interval }}$

1 merupakan nilai terendah dari skala.

5 merupakan nilai tertinggi dari skala.

33 merupakan jumlah responden.

Nilai tertinggi $\mathrm{x}=5 \times 33=165$

Nilai terendah $y=1 \times 33=33$ 
Banyaknya interval $=5$

Mencari interval $=\frac{\text { nilai tertinggi }- \text { nilai terendah }}{\text { banyaknya interval }}=\frac{165-33}{5}=\frac{132}{5}=26,4=26$

Maka interval yang diperoleh adalah 26 yaitu:

1. $29-55 \quad$ = sangat tidak diterima

2. 56 - 82 = tidak diterima

3. 83 - 109 = cukup diterima

4. $110-136$ = diterima

5. $137-163$ = sanqat diterima

Dapat diperoleh rata-rata (mean):

$\underline{130+124+127+131+123+116+126+132}=\underline{1009}=126,125=126$

8

Nilai dimensi penggunaan (usability) yang diperoleh adalah 126, masuk ke dalam kategori diterima.

Dimensi kualitas informasi (information quality)

Tabel 5. Perhitungan nilai dimensi kualitas informasi (information quality)

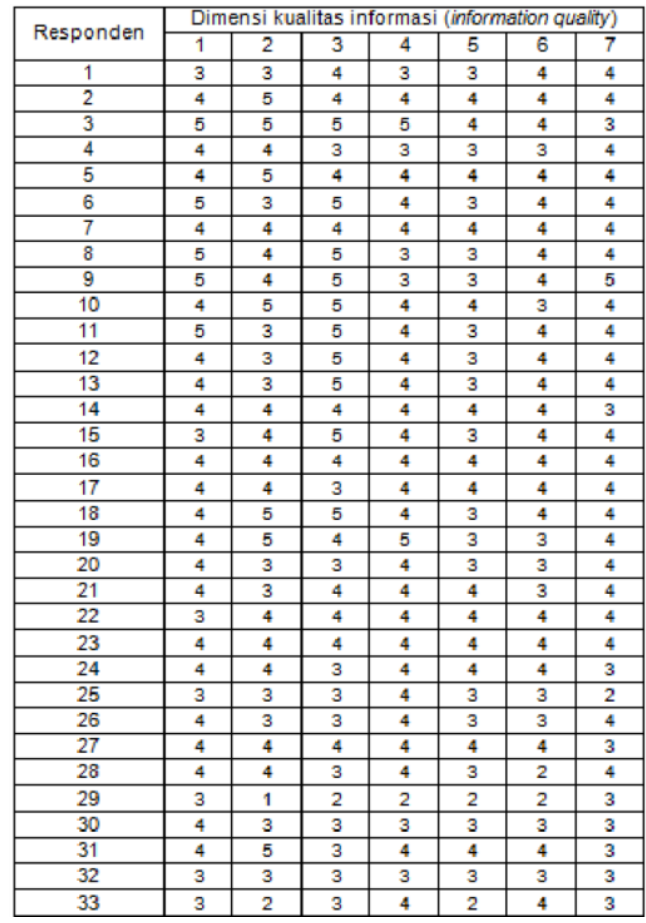

Tabel 6. Jumlah responden pada dimensi kualitas informasi (information quality)

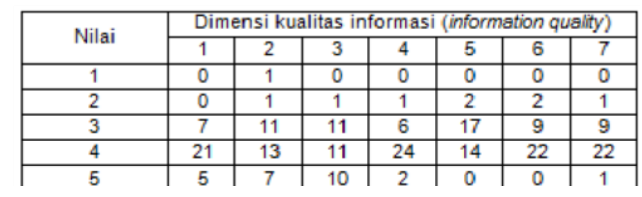


Nilai dari variabel-variabel dan total nilai dimensi kualitas informasi (information quality) terdapat pada table 7.

Tabel 7. Total nilai dimensi kualitas informasi (information quality)

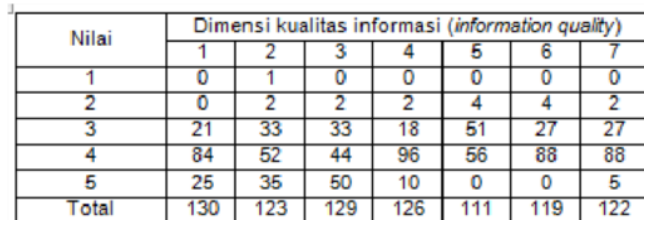

Dapat diperoleh rata-rata (mean):

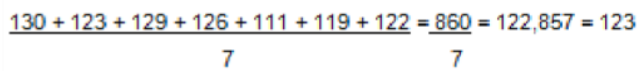

Nilai dimensi informasi (information quality) yang diperoleh adalah 123, masuk ke dalam kategori diterima.

Dimensi kualitas interaksi (interaction quality)

Tabel 8. Perhitungan nilai dimensi kualitas interaksi (Interaction quality)

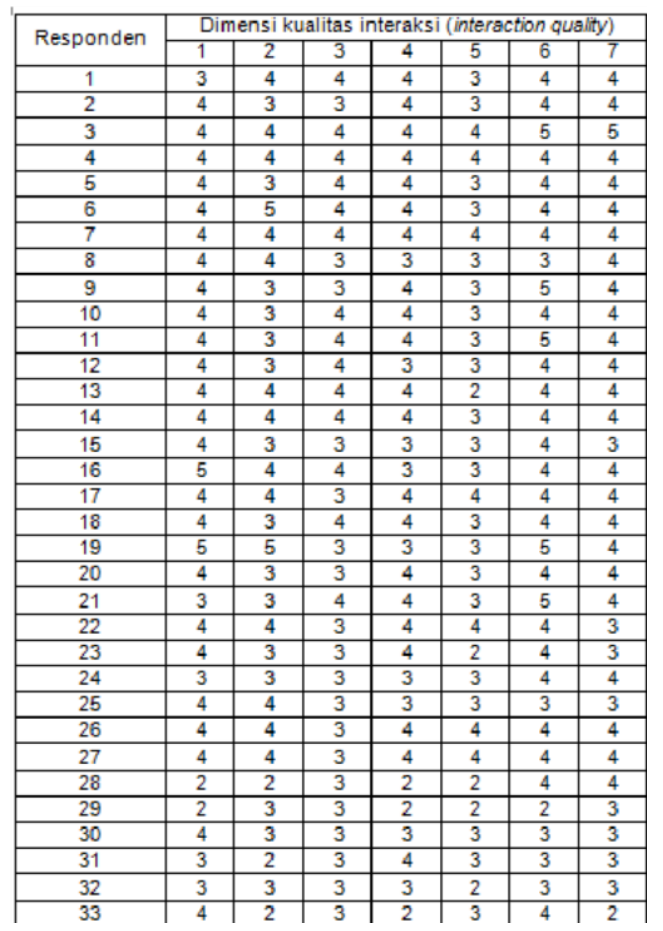

Tabel 9. Jumlah responden pada dimensi kualitas interaksi (Interaction quality)

\begin{tabular}{|c|c|c|c|c|c|c|c}
\hline \multirow{2}{*}{ Nilai } & \multicolumn{6}{|c}{ Dimensi kualitas interaksi (interaction quality) } \\
\cline { 2 - 8 } & 1 & 2 & 3 & 4 & 5 & 6 & 7 \\
\hline 1 & 0 & 0 & 0 & 0 & 0 & 0 & 0 \\
\hline 2 & 2 & 3 & 0 & 3 & 5 & 1 & 1 \\
\hline 3 & 5 & 15 & 19 & 9 & 21 & 5 & 8 \\
\hline 4 & 24 & 13 & 14 & 21 & 7 & 22 & 23 \\
\hline 5 & 2 & 2 & 0 & 0 & 0 & 5 & 1
\end{tabular}


Nilai dari variabel-variabel dan total nilai dimensi kualitas interaksi (interaction quality) terdapat pada tabel 10 .

Tabel 10. Total nilai dimensi kualitas interaksi (Interaction quality)

\begin{tabular}{|c|c|c|c|c|c|c|c|}
\hline \multirow{2}{*}{ Nilai } & \multicolumn{6}{|c|}{ Dimensi kualitas interaksi (interaction quality) } \\
\cline { 2 - 9 } & 1 & 2 & 3 & 4 & 5 & 6 & 7 \\
\hline 1 & 0 & 0 & 0 & 0 & 0 & 0 & 0 \\
\hline 2 & 4 & 6 & 0 & 6 & 10 & 2 & 2 \\
\hline 3 & 15 & 45 & 57 & 27 & 63 & 15 & 24 \\
\hline 4 & 96 & 52 & 56 & 84 & 28 & 88 & 92 \\
\hline 5 & 10 & 10 & 0 & 0 & 0 & 25 & 5 \\
\hline Total & 125 & 113 & 113 & 117 & 101 & 130 & 123 \\
\hline
\end{tabular}

Dapat diperoleh rata-rata (mean):

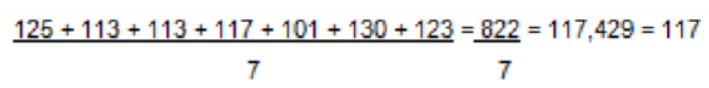

Nilai dimensi interaksi (interaction quality) yang diperoleh adalah 117, masuk ke dalam kategori diterima.

Dimensi keseluruhan kualitas website (overall impression)

Tabel 11. Perhitungan nilai dimensi keseluruhan kualitas website (overall impression)

\begin{tabular}{|c|c|}
\hline Responden & Dimensi keseluruhan kualitas website (overall impression) \\
\hline 1 & 4 \\
\hline 2 & 4 \\
\hline 3 & 4 \\
\hline 4 & 4 \\
\hline 5 & 4 \\
\hline 6 & 4 \\
\hline 7 & 4 \\
\hline 8 & 4 \\
\hline 9 & 5 \\
\hline 10 & 5 \\
\hline 11 & 4 \\
\hline 12 & 4 \\
\hline 13 & 4 \\
\hline 14 & 3 \\
\hline 15 & 4 \\
\hline 16 & 4 \\
\hline 17 & 4 \\
\hline 18 & 4 \\
\hline 19 & 4 \\
\hline 20 & 4 \\
\hline 21 & 4 \\
\hline 22 & 4 \\
\hline 23 & 3 \\
\hline 24 & 4 \\
\hline 25 & 3 \\
\hline 26 & 4 \\
\hline 27 & 4 \\
\hline 28 & 2 \\
\hline 29 & 2 \\
\hline 30 & 3 \\
\hline 31 & 3 \\
\hline 32 & 3 \\
\hline 33 & 3 \\
\hline
\end{tabular}

Tabel 12. Jumlah responden pada dimensi keseluruhan kualitas website (overall impression)

\begin{tabular}{|c|c|}
\hline Nilai & Dimensi keseluruhan kualitas website (overall impression) \\
\hline 1 & 0 \\
\hline 2 & 2 \\
\hline 3 & 7 \\
\hline 4 & 22 \\
\hline 5 & 2 \\
\hline
\end{tabular}


Nilai dari variabel-variabel dan total nilai dimensi keseluruhan kualitas website (overall impression) terdapat pada table 13 .

Tabel 13. Total nilai dimensi keseluruhan kualitas website (overall impression)

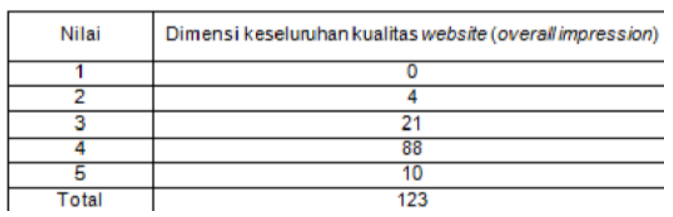

Secara keseluruhan kualitas website BPRS Al Salaam Amal Salman sudah bagus, nilainya 123 masuk ke dalam kategori diterima.

\section{Analisis korelasi}

Teknik korelasi linear yang bertujuan untuk mengetahui seberapa kuat hubungan antara variabel satu dengan yang lainnya, Berikut hasil pemetaan dari setiap dimensi terhadap keseluruhan kualitas website.

Korelasi dimensi penggunaan (usability) (x1) terhadap keseluruhan kualitas website (overall impression) (y)

Tabel 14. Tabel korelasi dimensi penggunaan terhadap keseluruhan kualitas website

\begin{tabular}{|c|c|c|c|c|c|}
\hline Responden & $x_{1}$ & $y$ & $x_{1} y$ & $x_{2}$ & $y^{2}$ \\
\hline 1 & 29 & 4 & 116 & 841 & 16 \\
\hline 2 & 32 & 4 & 128 & 1024 & 16 \\
\hline 3 & 40 & 4 & 160 & 1600 & 16 \\
\hline 4 & 29 & 4 & 116 & 841 & 16 \\
\hline 5 & 32 & 4 & 128 & 1024 & 16 \\
\hline 6 & 35 & 4 & 140 & 1225 & 16 \\
\hline 7 & 32 & 4 & 128 & 1024 & 16 \\
\hline 8 & 30 & 4 & 120 & 900 & 16 \\
\hline 9 & 35 & 5 & 175 & 1225 & 25 \\
\hline 10 & 31 & 5 & 155 & 961 & 25 \\
\hline 11 & 31 & 4 & 124 & 961 & 16 \\
\hline 12 & 35 & 4 & 140 & 1225 & 16 \\
\hline 13 & 34 & 4 & 136 & 1156 & 16 \\
\hline 14 & 32 & 3 & 96 & 1024 & 9 \\
\hline 15 & 28 & 4 & 112 & 784 & 16 \\
\hline 16 & 32 & 4 & 128 & 1024 & 16 \\
\hline 17 & 32 & 4 & 128 & 1024 & 16 \\
\hline 18 & 33 & 4 & 132 & 1089 & 16 \\
\hline 19 & 31 & 4 & 124 & 961 & 16 \\
\hline 20 & 32 & 4 & 128 & 1024 & 16 \\
\hline 21 & 31 & 4 & 124 & 961 & 16 \\
\hline 22 & 31 & 4 & 124 & 961 & 16 \\
\hline 23 & 31 & 3 & 93 & 961 & 9 \\
\hline 24 & 29 & 4 & 116 & 841 & 16 \\
\hline 25 & 26 & 3 & 78 & 676 & 9 \\
\hline 26 & 26 & 4 & 104 & 676 & 16 \\
\hline 27 & 32 & 4 & 128 & 1024 & 16 \\
\hline & & & & & \\
\hline
\end{tabular}




\begin{tabular}{|c|c|c|c|c|c|}
\hline 28 & 26 & 2 & 52 & 676 & 4 \\
\hline 29 & 27 & 2 & 54 & 729 & 4 \\
\hline 30 & 25 & 3 & 75 & 625 & 9 \\
\hline 31 & 30 & 3 & 90 & 900 & 9 \\
\hline 32 & 24 & 3 & 72 & 576 & 9 \\
\hline 33 & 26 & 3 & 78 & 676 & 9 \\
\hline Jumlah & 1009 & 123 & 3802 & 31219 & 473 \\
\hline
\end{tabular}

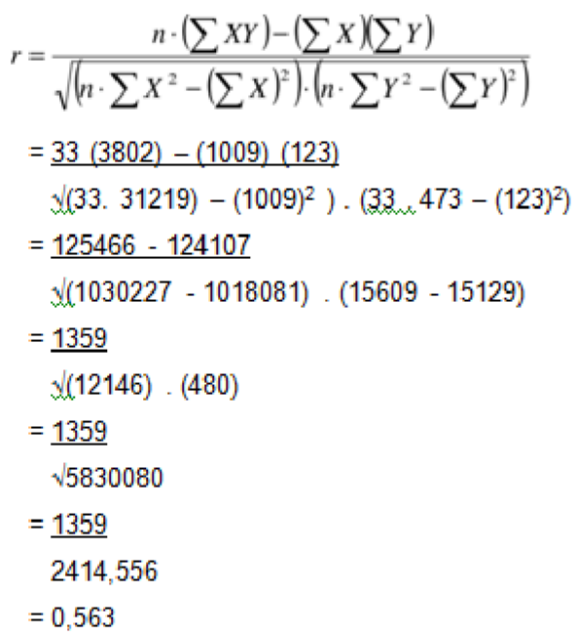

Hasil dari korelasi antara dimensi penggunaan (usability) (x1) dengan keseluruhan kualitas website (overall impression ) (y) bahwa thitung $=3,795>$ tabel $=2,03951$, maka Ho ditolak dan Ha diterima.

Nilai R Square adalah 0,317 yang merupakan hasil kuadran dari koefisien korelasi $(0,563 \times 0,563=$ 0,317). Maka dapat disimpulkan kontribusi nilai dimensi penggunaan (usability) terhadap keseluruhan kualitas website (overall impression) sebesar 0,317 dengan tingkat hubungan rendah karena berada pada skala $0,20-0,399$.

Korelasi dimensi kualitas informasi (information quality) (x2) terhadap keseluruhan kualitas website (overall impression) (y)

Tabel 15. Tabel korelasi dimensi kualitas informasi terhadap keseluruhan kualitas website

\begin{tabular}{|c|c|c|c|c|c|}
\hline Responden & $\mathrm{x}_{2}$ & $\mathrm{y}$ & $\mathrm{x}_{\mathbf{3}} \mathrm{y}$ & $\mathrm{x}_{2}{ }^{2}$ & $\mathrm{y}^{2}$ \\
\hline 1 & 24 & 4 & 96 & 576 & 16 \\
\hline 2 & 29 & 4 & 116 & 841 & 16 \\
\hline 3 & 31 & 4 & 124 & 961 & 16 \\
\hline 4 & 24 & 4 & 96 & 576 & 16 \\
\hline 5 & 29 & 4 & 116 & 841 & 16 \\
\hline 6 & 28 & 4 & 112 & 784 & 16 \\
\hline 7 & 28 & 4 & 112 & 784 & 16 \\
\hline 8 & 28 & 4 & 112 & 784 & 16 \\
\hline 9 & 29 & 5 & 145 & 841 & 25 \\
\hline 10 & 29 & 5 & 145 & 841 & 25 \\
\hline 11 & 28 & 4 & 112 & 784 & 16 \\
\hline \hline 12 & 27 & 4 & 108 & 729 & 16 \\
\hline 13 & 27 & 4 & 108 & 729 & 16 \\
\hline 14 & 27 & 3 & 81 & 729 & 9 \\
\hline & & & & & \\
\hline- & & & & \\
\hline
\end{tabular}




\begin{tabular}{|c|c|c|c|c|c|}
\hline 15 & 27 & 4 & 108 & 729 & 16 \\
\hline 16 & 28 & 4 & 112 & 784 & 16 \\
\hline 17 & 27 & 4 & 108 & 729 & 16 \\
\hline 18 & 29 & 4 & 116 & 841 & 16 \\
\hline 19 & 28 & 4 & 112 & 784 & 16 \\
\hline 20 & 24 & 4 & 96 & 576 & 16 \\
\hline 21 & 26 & 4 & 104 & 676 & 16 \\
\hline 22 & 27 & 4 & 108 & 729 & 16 \\
\hline 23 & 28 & 3 & 84 & 784 & 9 \\
\hline 24 & 26 & 4 & 104 & 676 & 16 \\
\hline 25 & 21 & 3 & 63 & 441 & 9 \\
\hline 26 & 24 & 4 & 96 & 576 & 16 \\
\hline 27 & 27 & 4 & 108 & 729 & 16 \\
\hline 28 & 24 & 2 & 48 & 576 & 4 \\
\hline 29 & 15 & 2 & 30 & 225 & 4 \\
\hline 30 & 22 & 3 & 66 & 484 & 9 \\
\hline 31 & 27 & 3 & 81 & 729 & 9 \\
\hline 32 & 21 & 3 & 63 & 441 & 9 \\
\hline 33 & 21 & 3 & 63 & 441 & 9 \\
\hline Jumlah & 860 & 123 & 3253 & 22750 & 473 \\
\hline
\end{tabular}

\begin{tabular}{|c|c|}
\hline$r=\frac{n \cdot\left(\sum X Y\right)-\left(\sum X\right)\left(\sum Y\right)}{\sqrt{\left(\sum Y^{2}-\left(\sum Y\right)^{2}\right) \cdot\left(\sum Y^{2}-\left(\sum Y\right)^{2}\right.}}$ & $t=\frac{r \sqrt{n-2}}{\sqrt{1-r^{2}}}$ \\
\hline 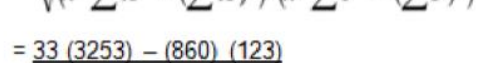 & 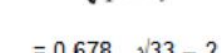 \\
\hline$\sqrt{\left.(33.22750)-(860)^{2}\right)} \cdot\left(33.473-(123)^{2}\right)$ & $\sqrt{\left(1-(0,678)^{2}\right.}$ \\
\hline$=\frac{107349-105780}{\sqrt{(750750-739600) \cdot(15609-15129)}}$ & $=\frac{0.678, \sqrt{3} 1}{\sqrt{(1-0,4597)}}$ \\
\hline$=\frac{1569}{\sqrt{(11150)}}$ & $=\frac{0.678 \cdot 5.568}{\sqrt{0.5403}}$ \\
\hline $\begin{aligned} & \frac{1(11150) \cdot(480)}{1569} \\
& \sqrt{5352000}\end{aligned}$ & $=\frac{3.775}{0.7351}$ \\
\hline$=\frac{1569}{2313,4389}$ & $=5,135$ \\
\hline
\end{tabular}

Hasil dari korelasi antara dimensi kualitas informasi (information quality) (x1) dengan keseluruhan kualitas website overall impression) (y) bahwa thitung $=5,135>$ tabel $=2,03951$, maka Ho ditolak dan Ha diterima.

Nilai R Square adalah 0,460 yang merupakan hasil kuadran dari koefisien korelasi $(0,678 \times 0,678=$ 0,460). Maka dapat disimpulkan kontribusi nilai dimensi kualitas informasi (information quality) terhadap keseluruhan kualitas website sebesar 0,460 dengan tingkat hubungan sedang karena berada pada skala $0,40-0,599$.

Korelasi dimensi kualitas interaksi (interaction quality) (x2) terhadap keseluruhan kualitas website (overall impression) (y)

Tabel 16. Tabel korelasi dimensi kualitas interaksi terhadap keseluruhan kualitas website

\begin{tabular}{|c|c|c|c|c|c|}
\hline Responden & $x_{2}$ & $y$ & $x_{2 y}$ & $x_{2}{ }^{2}$ & $y^{2}$ \\
\hline 1 & 26 & 4 & 104 & 676 & 16 \\
\hline 2 & 25 & 4 & 100 & 625 & 16 \\
\hline 3 & 30 & 4 & 120 & 900 & 16 \\
\hline 4 & 28 & 4 & 112 & 784 & 16 \\
\hline
\end{tabular}




\begin{tabular}{|c|c|c|c|c|c|}
\hline 5 & 26 & 4 & 104 & 676 & 16 \\
\hline 6 & 28 & 4 & 112 & 784 & 16 \\
\hline 7 & 28 & 4 & 112 & 784 & 16 \\
\hline 8 & 24 & 4 & 96 & 576 & 16 \\
\hline 9 & 26 & 5 & 130 & 676 & 25 \\
\hline 10 & 26 & 5 & 130 & 676 & 25 \\
\hline 11 & 27 & 4 & 108 & 729 & 16 \\
\hline 12 & 25 & 4 & 100 & 625 & 16 \\
\hline 13 & 26 & 4 & 104 & 676 & 16 \\
\hline 14 & 27 & 3 & 81 & 729 & 9 \\
\hline 15 & 23 & 4 & 92 & 529 & 16 \\
\hline 16 & 27 & 4 & 108 & 729 & 16 \\
\hline 17 & 27 & 4 & 108 & 729 & 16 \\
\hline 18 & 26 & 4 & 104 & 676 & 16 \\
\hline 19 & 28 & 4 & 112 & 784 & 16 \\
\hline 20 & 25 & 4 & 100 & 625 & 16 \\
\hline 21 & 26 & 4 & 104 & 676 & 16 \\
\hline 22 & 26 & 4 & 104 & 676 & 16 \\
\hline 23 & 23 & 3 & 69 & 529 & 9 \\
\hline 24 & 23 & 4 & 92 & 529 & 16 \\
\hline 25 & 23 & 3 & 69 & 529 & 9 \\
\hline 26 & 27 & 4 & 108 & 729 & 16 \\
\hline 27 & 27 & 4 & 108 & 729 & 16 \\
\hline 28 & 19 & 2 & 38 & 361 & 4 \\
\hline 29 & 17 & 2 & 34 & 289 & 4 \\
\hline 30 & 22 & 3 & 66 & 484 & 9 \\
\hline 31 & 21 & 3 & 63 & 441 & 9 \\
\hline 32 & 20 & 3 & 60 & 400 & 9 \\
\hline 33 & 20 & 3 & 60 & 400 & 9 \\
\hline Jumlah & 822 & 123 & 3112 & 20760 & 473 \\
\hline
\end{tabular}

\begin{tabular}{|c|c|}
\hline 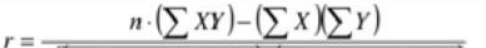 & $r \sqrt{n-2}$ \\
\hline$\sqrt{\left(n \cdot \sum X^{2}-\left(\sum X\right)^{2}\right) \cdot\left(n \cdot \sum Y^{2}-\left(\sum Y\right)^{2}\right)}$ & $t=\frac{\sqrt{1-r^{2}}}{\sqrt{1-r^{2}}}$ \\
\hline$=\underline{33(3112)-(822)(123)}$ & $=0.749 \cdot \sqrt{3} 3-2$ \\
\hline$\left.\sqrt{ }(33.20760)-(822)^{2}\right) \cdot\left(33.473-(123)^{2}\right)$ & 型 \\
\hline$=\underline{102696-101106}$ & $0,(40)^{-}$ \\
\hline$\sqrt{ }(685080-675684) \cdot(15609-15129)$ & $=0.149$ \\
\hline$=\underline{1590}$ & $\sqrt{ }(1-0,561)$ \\
\hline$\sqrt{ }(9396) \cdot(480)$ & $=0.749,5.568$ \\
\hline$=\underline{1590}$ & $\sqrt{0,439}$ \\
\hline$\sqrt{4510080}$ & $=\underline{4.170}$ \\
\hline$=\underline{1590}$ & 0,663 \\
\hline 2123,695 & $=6.289$ \\
\hline$=0.749$ & \\
\hline
\end{tabular}

Hasil dari korelasi antara dimensi kualitas interaksi (interaction quality) (x1) dengan keseluruhan kualitas website (overall impression) (y) bahwa thitung $=6,289>$ tabel $=2,03951$, maka Ho ditolak dan Ha diterima.

Nilai R Square adalah 0,561 yang merupakan hasil kuadran dari koefisien korelasi $(0,749 \times 0,749=$ 0,561). Maka dapat disimpulkan kontribusi nilai dimensi kualitas interaksi (interaction quality) terhadap keseluruhan kualitas website sebesar 0,561 dengan tingkat hubungan sedang karena berada pada skala $0,40-0,599$.

\section{SIMPULAN DAN SARAN}

\section{Kesimpulan}

Pengukuran kualitas sebuah website dapat dilakukan dengan cara melakukan pendekatan metode webqual dimana dalam metode webqual terdapat dimensi-dimensi yang dapat mempresentasikan sebuah website yang baik dan menarik. 
Dalam penelitian ini dilakukan penilaian terhadap keseluruhan kualitas website BPRS Al Salaam Amal Salman dengan menggunakan pendekatan metode webqual, dimana hasil dari penelitian ini dapat disimpulkan yaitu : Nilai dimensi penggunaan (usability) masuk ke dalam kategori diterima, nilai dimensi informasi (information quality) masuk ke dalam kategori diterima, nilai dimensi interaksi (interaction quality) masuk ke dalam kategori diterima, dan nilai dimensi keseluruhan kualitas website (overall impression) masuk ke dalam kategori diterima.

\section{Saran}

Secara umum pengambil kebijakan atau manajemen organisasi harus meningkatkan kualitas sistem, kualitas informasi dan kualitas interaksi (layanan) agar berdampak bagi kinerja yang merupakan pengukur dari kesuksesan website BPRS Al Salaam Amal Salman.

Untuk meningkatkan kualitas website BPRS Al Salaam Amal Salman, kualitas website perlu diteliti lebih lanjut tentang faktor teknis apa saja yang mempengaruhinya.

Penelitian ini hanya melibatkan responden dengan jumlah yang sedikit, untuk penelitian selanjutnya perlu dilibatkan responden yang cukup banyak dengan mengambil jumlah sampel besar sehingga hasilnya lebih berdampak luas.

Penelitian ini bisa juga menggunakan metode yang lain sebagai bahan evaluasi penerapan website BPRS Al Salaam Amal Salman sehingga pengembangan website tersebut lebih optimal.

\section{DAFTAR RUJUKAN}

Gay, L.R. dan Diehl, P.L. (1992), Research Methods for Business and. Management, MacMillan Publishing Company, New York.

Irawan, Candra. 2012. "Evaluasi Kualitas Website Pemerintah Daerah Dengan Menggunakan Webqual (Studi Kasus Pada Kabupaten Ogan Ilir)". Sistem Informasi Fakultas Ilmu Komputer. Universitas Sriwijaya. Palembang.

Maslan, Andi. "Pengukuran Kualitas Layanan Website Pemerintah Kota Batam Menggunakan Metode Webqual 4.0”. Teknik Informatika. Universitas Putera Batam.

Nasution, Miftah dan Mudjahidin. 2013. "Analisis Kualitas Layanan Website Kantor Pelayanan Perbendaharaan Negara (KPPN) Surabaya I Dengan Menggunakan Webqual”. Sistem Informasi Fakultas Teknik Informatika. Institut Teknologi Sepuluh Nopember (ITS). Surabaya.

Pressman, Roger S. 2010. Software Engineering: A Practitioner's Approach, Seventh Edition. ANDI. Yogyakarta.

Sanjaya, Iman. 2012. "Pengukuran Kualitas Layanan Website Kementerian Kominfo Dengan Menggunakan Metode Webqual 4.0". Pusat Penelitian dan Pengembangan Sumber Daya dan Perangkat Pos dan Informatika Badan Litbang SDM, Kemkominfo RI. Jakarta.

Siregar, Syofian, 2013. "Statistika parametrik untuk penelitian kuantitatif: dilengkapi dengan perhitungan manual dan aplikasi SPSS versi 17, Bumi Aksara, Jakarta.

Sugiyono. 2001. Statistika untuk Penelitian, Bandung: Alfabeta.

Wicaksono, Bayu Luhur. Susanto, Adhi dan Winarno, Wing Wahyu. 2012. "Evaluasi Kualitas Layanan Website PUSDIKLAT BPK RI Menggunakan Metode Webqual Modification dan Importance Performance Analysis". BPK RI Perwakilan Jawa Timur, Fakultas Teknik Elektro dan Informatika UGM Yogyakarta, STIE YKPN Yogyakarta. 